\title{
Enhancing the Capability of Language Teachers in Developing Lesson Plans Through Academic Supervision of Staff Meeting Technique at SMP PABA Binjai
}

\author{
Dharwita Faradilla Nasution ${ }^{1 *}$ Saut Purba ${ }^{2}$ Darwin $^{3}$ \\ ${ }^{1,2,3}$ School of Postgraduate, Educational Administration, Universitas Negeri Medan, North Sumatera Province - \\ Indonesia \\ *Corresponding Author: dharwita95@gmail.com
}

\begin{abstract}
This study aims to determine the ability of language teachers in preparing Lesson Plans (RPP) through academic supervision of Staff Meeting technique at SMP PABA Binjai. The hypothesis of this research action is that the application of academic supervision of the Staff Meeting technique can improve the ability of language teachers at SMP PABA Binjai. The subjects of this study were five language teachers. The research instrument used to determine the teacher's ability in preparing the Lesson Plan (RPP) is an interview guide and an observation sheet. To observe the academic supervision activities of staff meeting techniques using an observation sheet. The research design used is school action research which refers to the Kemmis and Taggart research model. The implementation is designed in the form of cycles, as many as two cycles. Each cycle consists of four stages of activity, namely: planning, implementation, observation and reflection. The results showed that the ability of language teachers in preparing lesson plans in the first cycle reached an average value of $85.43 \%$ in the Good category and the second cycle reached an average value of $91.85 \%$ in the Very Good category. The findings of this study indicate that the application of academic supervision of staff meeting techniques can improve the ability of language teachers in developing lesson plans at SMP PABA Binjai.
\end{abstract}

Keywords: Teacher's Competences, Lesson Plan, Academic Supervision, Staff Meeting Technique.

\section{INTRODUCTION}

One form of effort to improve the quality of education and the quality of human resources is through the learning process in schools, where the teacher is the main actor. However, it is common knowledge that the quality of teachers in Indonesia is generally low. The evidence that supports this conclusion is the performance data of school principals and junior high school teachers issued by the Division of Utilization and Services for Data and Statistics of Education and Culture of Indonesia (2016:73). The reality on the ground also shows that teachers do not yet have adequate competence, especially in terms of designing or planning lessons. This condition occurs in teachers at all levels of education and subjects, including in public and private junior high schools in Binjai. Waruwu (2019:6) stated that about $60 \%$ of the 57 teachers assisted by a supervisor were still copy-pasting in making the Learning Implementation Plan. Based on the learning observations that the researchers did, it was found that students did not participate actively in learning activities. Teachers still dominate learning activities and act as the only source of learning for students in the classroom. Even teachers tend to feel that they have not taught if they have not explained clearly a material to students by lecturing. From the aspect of learning evaluation, the researcher also found that the evaluation carried out by the teacher was only on the cognitive aspect, and had not been guided by the indicators contained in the syllabus and lesson plans. In general, at this time there are symptoms or phenomena in the learning process, often without being supported by a good learning implementation plan, the implementation of learning carried out without preparation from the teacher makes the learning process unacceptable and unattractive and even unpleasant for students. If such a learning planning situation is left unattended for a long time, it can cause a decrease in student interest in learning in participating in learning so that student learning activities become low which may have an impact on low student learning outcomes as well. Therefore, the potential of teacher 
resources still needs to be honed and developed so that they can perform their functions optimally.

One of the efforts that can be done is to streamline the implementation of academic supervision by school principals and school supervisors. Supervision has a strategic and important position in overcoming the problem of improving the quality of education and the quality of human resources, namely by fostering and developing the professional abilities of teachers and school principals. Mark et al (in Purba, 2013:3) stated that one of the extrinsic factors that contribute significantly to work motivation, achievement and teacher professionalism is supervision services. According to Priansa (2018:135) supervision in education is carried out in the context of mentoring, directing and coaching towards improving the quality of educational performance through a systematic and dialogical process. Therefore, it can be understood that academic supervision is an effort and or service to provide coaching assistance provided by a supervisor to teachers in an effort to improve teacher professionalism and learning quality. Through supervision, a supervisor can make predictions and evaluations as early as possible on things that become obstacles in carrying out a work program, so that supervisors can take strategic actions which are solutions to problems experienced by teachers so far. In addition, supervisors can also analyze various facilities and advantages in schools that will be potential factors to be developed at the school, so that in the end all elements in the school can achieve the goals of providing education in schools effectively.

The Ministry of National Education (in Priansa, 2018: 219) states that academic supervision is an effort to help teachers develop their abilities in achieving learning goals, thus the essence of academic supervision is not to assess teacher performance in managing the learning process but to assist teachers in developing their professional abilities.

Starting from these problems, the author seeks to design supervision activities that can overcome all of the problems above. One of the supervision techniques that can be used as an alternative is the technical supervision of staff meetings.

According to Karwati (2013:226): "Staff meeting is defined as a group learning activity consisting of a number of teachers who are solving a problem being faced through conversation". Thus, the Staff Meeting allows teachers to work together and discuss to solve the problems they face openly and without any feelings of fear and anxiety.

Based on the description above, the authors are very interested in conducting a study on "Enhancing the Capability of Language Teachers in Developing Lesson Plans through Academic Supervision of Staff Meeting Technique at SMP PABA Binjai".

\section{METHOD}

This research uses school action research. School action research is research that uses cycles, namely research that is carried out continuously or repeatedly until the research objectives are achieved. This action is planned for two or more cycles depending on the achievement of the objectives. The academic supervision of the technical staff meeting is carried out in collaboration between school supervisors, supervised teachers and researchers. The stages of the cycle are as follows: (1) planning; (2) implementation of activities; (3) observation or observation; and (4) reflection.

This research was conducted in a school, namely PABA Private Junior High School Binjai. The subjects of this study were five language teachers, consisting of 3 English teachers and 2 Indonesian teachers. The research instrument used to determine the teacher's ability in preparing the Learning Implementation Plan is an interview guide and an observation sheet. Meanwhile, to observe the academic supervision activities of staff meeting techniques using an observation sheet. The research design used is school action research which refers to the Kemmis and Taggart research model.

Data collection techniques used in this study are as follows: (1) Observation, (2) Interview, and (3) Documentation. The tools used to collect data include: (a) an assessment sheet for the study of the Learning Implementation Plan, and (b) an observation sheet for the supervision implementation process.

\section{RESULTS AND DISCUSSION}

\subsection{Results}

Descriptions of research results are made in an integrated and systematic manner with a cyclical strategy. This research was conducted in two cycles. Each cycle consists of four stages, namely planning, implementation, observation, and reflection carried out between supervisors and teachers with the aim of improving the ability of teachers in preparing lesson plans with technical supervision of staff meetings. Researchers conducted interviews with supervisors that were conducted previously. Based on the results of these interviews, preliminary data obtained that in general the ability of teachers is still low, especially in planning learning and in carrying out learning activities. One of them is that the teacher does not follow the procedures or learning steps contained in the Learning Implementation Plan. The data is reinforced by the results of observations in the pre-cycle conducted by researchers on language teachers at SMP PABA Binjai, where the results of the study of the RPP that have been prepared by the teacher are still not in accordance with the standards set by the government. 
This study uses school action research which was carried out on March 17, 2020 to May 23, 2020 with five language teachers at the PABA Binjai Private Junior High School as research subjects. The description of the results of this research is described in stages consisting of two, namely (1) the first cycle is carried out on 17 to 31 March 2020, and (2) the second cycle is carried out from 9 May to 23 May 2020.

Researchers held meetings with supervisors, principals, vice principals and teachers before carrying out academic supervision activities. Staff Meeting techniques, as coordination to equalize perceptions about the research objectives and to find out how conditions were in the field, then held a meeting with teachers (subjects) to determine competence the beginning of the teacher in developing the Learning Implementation Plan.

The results of the assessment of the ability of language teachers in developing lesson plans in the precycle are described in the following table

Table 1. Results of Assessment of Language Teachers' Ability in Developing Lesson Plans in PreCycle

\begin{tabular}{|l|l|l|l|l|l|l|c|}
\hline & \multicolumn{5}{|c|}{ Teacher's Code } & Amount & Average \\
\hline & Gr 1 & Gr 2 & Gr 3 & Gr 4 & Gr 5 & & \\
\hline Amount & 71,00 & 68,00 & 69,00 & 72,00 & 71,00 & 351 & 70,2 \\
\hline Score & 65,74 & 62,96 & 63,89 & 66,67 & 65,74 & 325 & 65 \\
\hline Descript & $\begin{array}{c}\text { Enou } \\
\text { gh }\end{array}$ & Less & Less & $\begin{array}{l}\text { Enoug } \\
\text { h }\end{array}$ & Enough & & Enough \\
\hline
\end{tabular}

The data shows that the initial competency value (precycle) of language teachers at SMP PABA BINJAI belongs to the low category (enough) and then the academic supervision of staff meeting techniques in cycle 1 is carried out.

Teachers and supervisors In Cycle 1 held a back meeting in a relaxed, friendly, and open atmosphere in the teacher's room. Next, the Supervisor informs the teacher of the results of previous observations, in the form of the value of the results of the lesson plans that have been made by the teacher. By using the assessment sheet instrument in preparing the lesson plans and seeing the difficulties faced by the teacher, it was found that the teacher still did not really understand the preparation of a good and correct lesson plan. Then, the supervisor asks and records any difficulties expressed by the teacher and then the teachers together carry out a re-analysis (review) of the lesson plans that are prepared so that the teacher knows better where the shortcomings are.

The results of the assessment of the ability of language teachers in developing lesson plans in cycle I can be described in the following table
Table 2. Results of Assessment of Language Teachers' Ability in Developing Lesson Plans in Cycle 1

\begin{tabular}{|c|c|c|c|c|c|c|c|}
\hline & \multicolumn{5}{|c|}{ Teacher's Code } & \multirow[t]{2}{*}{ Amount } & \multirow[t]{2}{*}{ Average } \\
\hline & Gr 1 & Gr 2 & Gr 3 & Gr 4 & Gr 5 & & \\
\hline Amount & 92.67 & 90.67 & 91.67 & 94.33 & 91.67 & 461.01 & 92.20 \\
\hline Score & 85.49 & 83.95 & 85.49 & 87.35 & 84.88 & 427.16 & 85.43 \\
\hline Descript & Good & Good & Good & Good & Good & Good & Good \\
\hline
\end{tabular}

To overcome further problems that occur in the first cycle, the efforts are made to increase the results and the teacher is able to prepare the lesson plans correctly in the second cycle in order to meet the indicators of research success, namely $100 \%$ of the teachers who are fostered are able to develop the lesson plans well or with the acquisition of average value 90 .

The results of the language teacher's ability to develop lesson plans in cycle II can be described in the following table.

Table 3. Results of Assessment of Language Teachers' Ability in Developing Lesson Plans in Cycle II

\begin{tabular}{|c|c|c|c|c|c|c|c|}
\hline & \multicolumn{5}{|c|}{ Teacher's Code } & Amount & Average \\
\hline & Gr 1 & Gr 2 & Gr 3 & Gr 4 & Gr 5 & & \\
\hline Amount & 98.67 & 99.33 & 97.00 & 101.33 & 99.00 & 495.33 & 99.06 \\
\hline Score & 91.36 & 91.98 & 90.43 & 93.83 & 91.67 & 459.27 & 91.85 \\
\hline Descript & $\begin{array}{l}\text { Very } \\
\text { Good }\end{array}$ & $\begin{array}{l}\text { Very } \\
\text { Good } \\
\end{array}$ & $\begin{array}{l}\text { Very } \\
\text { Good }\end{array}$ & $\begin{array}{l}\text { Very } \\
\text { Good }\end{array}$ & $\begin{array}{l}\text { Very } \\
\text { Good }\end{array}$ & $\begin{array}{l}\text { Very } \\
\text { Good }\end{array}$ & $\begin{array}{l}\text { Very } \\
\text { Good }\end{array}$ \\
\hline
\end{tabular}

Based on the table above, it can be concluded that the teacher's ability to develop lesson plans in cycle 2 increased compared to cycle 1 which was in the very good category.

\subsection{Discussion}

Based on the results of the study, it can be seen that the initial ability scores of five teachers in developing lesson plans before going through the academic supervision of the Staff Meeting technique were as many as five teachers $(100 \%)$ had not been able to develop lesson plans and none of the teachers $(0 \%)$ were able to prepare lesson plans with good and complete. In this preliminary study (pre-cycle) the teacher's ability reached a score of 70.2 (65\%). Therefore, the initial competency assessment that has been carried out can be used as a reference for taking action through academic supervision of the Staff Meeting technique.

After taking action through the technical academic supervision of the staff meeting in the first cycle, it can be seen that the five teachers $(100 \%)$ had an increase of up to $427.16(85.43 \%)$ in the Good category. The percentage increase in the ability of teachers from pre-cycle to cycle I is $20.43 \%$ but has not reached the success criteria. There are three components of the lesson plan that achieve the success criteria in the first cycle, namely the formulation of subject identity, the formulation of indicators and the 
formulation of the formulation of learning objectives with a presentation of a value of 91.11 for the formulation of subject identity and formulation of learning objectives and a value of 90.56 for the formulation of indicators. To overcome the problems that occurred in the first cycle, efforts were made to improve the results and the teacher was able to prepare the lesson plans correctly in the second cycle.

Based on the results in the second cycle, the five teachers $(100 \%)$ were able to develop the RPP correctly with a value exceeding the success criteria that had been set at 90.00 , which reached a value of 91.85 in the Very Good category. The percentage increase in the ability of teachers from cycle I to cycle II is $6.42 \%$.

The findings of this study make it clear that academic supervision of staff meeting techniques can improve teacher competence in developing lesson plans, because through this technique, the relationship between teachers and supervisors as well as relationships between teachers becomes more relaxed, fun, and open, so that it greatly contributes to the establishment of good communication where teachers have the opportunity to tell various difficulties or problems he faces to fellow co-workers and to supervisors.

\section{CONCLUSIONS}

\subsection{Conclusions}

The ability of the Language Teacher in developing lesson plans prior to the implementation of technical academic supervision of staff meetings reached a score of $70.2(65 \%)$ which was classified in the Enough category. After the implementation of academic supervision of staff meeting techniques, there was an increase in the ability of the Language Teacher to reach the Very Good category (Cycle I achieved a score of $427.16(85.43 \%)$ in the Good category and cycle 2 achieved a score of $459.27(91.85 \%)$ in the Very Good category.

The successful implementation of technical academic supervision of staff meetings is influenced by the supervisor's capacity in carrying out staff meetings including professional capacity, personal capacity, human relations, and leadership capacity. Another thing that is no less important is the teacher's own personality factor. Staff meetings will not be successful if the teacher does not want to cooperate, does not want to be guided and directed, does not want to know his weaknesses and does not want to improve it, and the teacher is expected to be free from pressure due to other problems.

\subsection{Implications}

Academic supervision of staff meeting techniques has been proven to improve the ability of teachers to develop lesson plans. Through the application of this technique, the teacher-supervisor relationship as well as the teacher-to-teacher relationship is more relaxed, fun, and open, thus contributing greatly to good communication. The teacher has the opportunity to share various difficulties or problems he faces and the handling of problems by the supervisor is also immediately resolved due to individual handling.

Because these findings have proven that staff meetings can improve the ability of teachers, every education staff who wants to help teachers improve their ability to develop lesson plans can use academic supervision of staff meeting techniques. Efforts to master this staff meeting technique can be carried out in three stages of activity, including (1) the initial meeting stage, (2) the implementation stage, and (3) the final meeting stage. This means that academic supervision of staff meeting techniques can be used as a reference for supervisors in carrying out services or supervision for teachers, and can be used as an alternative in dealing with problems and increasing the competence of teachers' professionalism, especially in developing lesson plans.

\subsection{Suggestions}

Based on the conclusions and implications of this study, some suggestions can be made as follows:

a. For supervisors, the concept of technical academic supervision of staff meetings should be used as an alternative in carrying out supervision to foster teachers, especially in developing lesson plans or various problems faced by teachers in their main tasks and supervisors should master a number of capacities including professional capacity, personal capacity, human relations, and leadership capacity. Among the four capacities referred to, mastery is more emphasized on the capacity of human relations.

b. Teachers should use the results of this study as a reference for fostering cooperative relationships with supervisors by being open, honest and responsible in conveying various problems encountered in learning, such as in the preparation of lesson plans to make it easier for supervisors to find solutions to problems being faced.

c. The principal as a supervisor should be able to help teachers to develop their teaching preparation or to overcome other problems related to the teacher's teaching task by implementing academic supervision of staff meeting techniques because the impact is very influential in improving the quality of schools.

\section{REFERENCES}

[1] Caruso, Joseph. 2007. Supervision in early childhood education. Columbia University: New York. 
[2] Darsono dan Siswandoko, Tjatjuk. 2011. Manajemen Sumber Daya Manusia Abad 21. Jakarta: Nusantara Consulting.

[3] Endayanto, Hermanyosepsanu dan Harumurti. 2014. Penilaian Belajar Siswa di Sekolah. Yogyakarta: Kanisisus.

[4] Imron, Ali. 2012. Supervisi Pembelajaran Tingkat Satuan pendidikan. Bumi Aksara: Jakarta

[5] Jelantik, Ketut. 2018. Mengenal Tugas Pokok dan Fungsi Pengawas Sekolah: Sebuah Gagasan Menuju Perbaikan Kualitas Secara Berkelanjutan. Deepublish. Yogyakarta

[6] Karwati, Euis dan Priansa, DJ. 2013. Kinerja dan Profesionalisme Kepala Sekolah. Bandung. Alfabeta.

[7] Leonard. (2015). "Kompetensi Tenaga Pendidik di Indonesia: Analisis Dampak Rendahnya Kualitas SDM Guru dan Solusi Perbaikannya”. Jurnal Formatif. Vol 5. https://www.researchgate.net/.../323571804

Kompetensi Tenaga Pendidik di Indonesia...akses 16 Januari 2020 pukul 22.35

[8] Mahmud, Hilal. 2015. Administrasi Pendidikan (Menuju Sekolah Efektif). Aksara Timur. Makassar

[9] Mukhtar dan Iskandar. 2013. Orientasi Baru Supervisi Pendidikan. Jakarta : Gaung Persada Press Group

[10] Mushlih, Aguslani dan Suryadi. 2018. Supervisi Pendidikan Teori dan Praktik. Bandung: Remaja Rosdakarya.

[11] Mulyasa. 2007. Standar Kompetensi dan Sertifikasi Guru. Bandung: PT. Remaja

[12] Mulyasa. 2018. Implementasi Kurikulum 2013 Revisi dalam Era Revolusi Industri 4.0. Jakarta: Bumi Aksara

[13] Peraturan Pemerintah Nomor 19 Tahun 2005 Bab IV Pasal 20

[14] Pidarta, Made. 2009. Supervisi Pendidikan Kontesktual. Jakarta: PT Renika Cipta

[15] Priansa, Donni Juni, dkk. 2018. Manajemen dan Supervisi Pendidikan. Pustaka Setia Rosdakarya. Bandung

[16] Purba, Saut. 2013. Supervisi Pendidikan dalam Rangka Meningkatkan Mutu dan Kinerja Guru. Unimed Press. Medan.

[17] Sagala, Syaiful. 2010. Konsep dan makna pembelajaran. Alfabeta: Bandung.

[18] Sahertian, Piet. A. 2010. Konsep Dasar \& Teknik Supervisi Pendidikan dalam Rangka Pengembangan Sumber Daya Manusia. Jakarta ; Rineka Cipta
[19] Sanjaya, Wina. 2010. Penelitian Tindakan Kelas, Prenada Media: Jakarta

[20] Sitohang, Mei Dina. 2015. Implementasi Supervisi Akademik Model Artistik Berbasis Manajemen Pendidikan untuk Meningkatkan Kinerja Guru Bahasa Indonesia. Unimed: Medan

[21] Suprihatiningrum, Jamil. 2013. Guru Profesional Pedoman Kinerja, Kualifikasi \& Kompetensi Guru. Yogyakarta: Ar Ruzz Media.

[22] Syafaruddin, dkk. 2014. Manajemen Kepengawasan Pendidikan. Citapustaka Media: Bandung

[23] Undang-Undang Sistem Pendidikan Nasional No. 20/2003

[24] Waruwu, Satria K.R. 2019. Peningkatan Kemampuan Guru Bahasa dalam Mengembangkan RPP Melalui Supervise Akademik Teknik Percakapan Pribadi di SMP Negeri 1 Moro'o Kabupaten Nias Barat. Tesis Unimed. Medan

[25] Zainuddin. 2016. "Supervisi Akademik dapat Meningkatkan Kompetensi Guru Melaksanakan Proses Pembelajaran”. Jurnal Pendidikan Serambi Ilmu. $\quad$ Vol $25 \quad$ No 2. http://jurnal2.serambimekkah.ac.id/... Diakses 26 Januari 2020 pukul 20:38 WIB 